\title{
Detorgan-3índía:
}

Telaah Pemikiran Kebangsaan

\author{
Volume 3 No 1 Tahun 2021 Hlmn. 1- 6 \\ Artikel Masuk 10 Desember 2020 I Artikel Diterima 31 Agustus 2021
}

\section{Implementasi Akuntansi Sosial Pengrajin Minyak Kelapa di Desa Kedungkamal Kabupaten Purworejo}

\author{
Diah Ayu Sekar Astuti*
}

Universitas Brawijaya, Jl. Veteran, Ketawanggede, Kec. Lowokwaru, Kota Malang, Indonesia, 65145

*diahayusekar20.da@gmail.com

\begin{abstract}
Abstrak
Penelitian ini bertujuan untuk mengetahui penerapan akuntansi sosial yang dilakukan pengrajin minyak kelapa. Penelitian ini di lakukan karena adanya keunikan proses bisnis pengrajin minyak kelapa yaitu adanya simbiosis mutualisme dengan masyarakat sekitar. Data yang diperoleh dianalisis menggunakan metode kualitatif deskriptif. Tempat penelitian di lakukan di Kelurahan Kedungkamal, Kecamatan Grabag, Kabupaten Purworejo. Sumber data yang di gunakan dalam penelitian ini adalah data primer. Pengumpulan data dengan partisipasi langsung wawancara pada pengrajin minyak kelapa maupun tokoh masyarakat setempat. Hasil penelitian menunjukkan pengrajin minyak kelapa membawa keberuntungan bagi masyarakat sekitar, yaitu hasil tanam pohon kelapa dibeli pengrajin kelapa dan penduduk desa mendapatkan pekerjaan. Dampak lingkungan diterima masyarakat berdasarkan nilai-nilai budaya Jawa yaitu prinsip kekeluargaan dan "tepo sliro". Implikasi penelitian ditujukan kepada aktor quintuple helix untuk menjaga keberlanjutan akuntansi hijau.
\end{abstract}

Kata Kunci: Tanggung Jawab Sosial, Dampak Lingkungan, Akuntansi Sosial, Pengrajin Minyak Kelapa, Quintuple Helix

\begin{abstract}
This study aims to determine the application of social accounting by coconut oil craftsmen. This research was conducted because of the unique business process of coconut oil craftsmen, namely the symbiotic mutualism with the surrounding community. The data obtained were analyzed using descriptive qualitative methods. The research site was conducted in Kedungkamal Village, Grabag District, Purworejo Regency. The data source used in this research is primary data. Data collection by direct participation in interviews with coconut oil craftsmen and local community leaders. The results showed that coconut oil craftsmen brought good luck to the surrounding community, namely the results of planting coconut trees were bought by coconut craftsmen and villagers got jobs. Environmental impacts are accepted by society based on Javanese cultural values, namely the principle of kinship and "tepo sliro". The research implication is aimed at various stakeholders to maintain the sustainability of green accounting.
\end{abstract}

Keywords: Social Responsibility, Environmental Impact, Social Accounting, Coconut Oil Craftsmen, Quintuple Helix
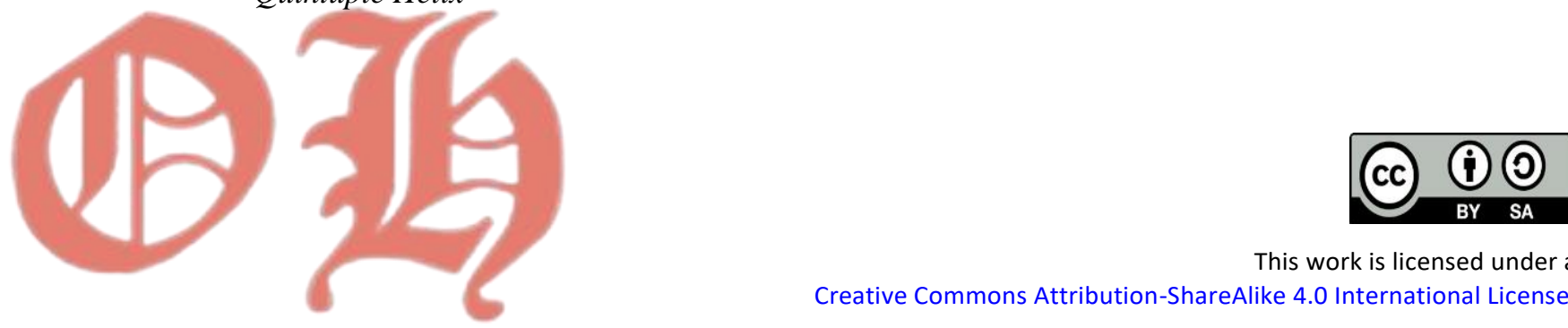

This work is licensed under a Creative Commons Attribution-ShareAlike 4.0 International License. 
Lingkungan selalu menarik untuk diperbincangkan terutama dalam dunia bisnis Perusahaan bertanggungjawab pada pengelolaan lingkungan sebagai wujud rasa terima kasih atas anugerah telah memanfaatkan alam semesta untuk mendapatkan keuntungan. Tanggung jawab social yang diterapkan dengan baik oleh perusahaan akan memunculkan keharmonisan dengan kehidupan masyarakat sekitar. Indonesia, khususnya dalam cakupan makalah ini, wilayah Jawa Tengah sangat kental dengan budaya hidup berdampingan, "tepo sliro", "unggah ungguh", yang ketiganya membawa makna mendalam dalam hidup bermasyarakat. Nilai-nilai yang telah tertanam mewujud sebagai budaya Jawa sehingga memberikan warna tersendiri bagi para pengusaha-pengusaha lokal.

Pengusaha lokal, yang sebagian besar merupakan Industri Kecil Menengah (IKM) telah membuktikan mampu bertahan dan tetap melakukan aktivitas produksi meskipun menghadapi masa-masa krisis perekonomian nasional. Sebagai contoh industri minyak kelapa yang telah berjalan sejak puluhan tahun lalu. Di Kabupaten Purworejo, terdapat produksi minyak kelapa yang merupakan usaha home industri yang banyak ditemukan antara lain di kecamatan Grabag dan Kedungkamal. Keberadaan industri minyak kelapa menjadi salah satu pilar ekonomi daerah yang memanfaatkan potensi sumberdaya alam berupa buah kelapa. Pohon kelapa merupakan tanaman utama yang tumbuh di hampir seluruh wilayah kecamatan, baik di wilayah pantai, perkebunan maupun sebagai tanaman pekarangan.

Produksi minyak kelapa menyerap banyak tenaga kerja dan meningkatkan pendapatan masyarakat sekitar. Di sisi lain, produksi minyak kelapa membawa dampak lingkungan berupa polusi udara, polusi tanah dan air. Berdasarkan pengamatan penulis, meskipun terdapat polusi yang sangat mengganggu, keharmonisan antara pengrajin minyak kelapa dengan masyarakat sekitar masih tetap terjaga. Keharmonisan ini merupakan fenomena menarik yang dapat didiskusikan dalam tataran kehidupan bermasyarakat maupun tinjauan akuntansi sosial. Pertanyaan mendasar yang memerlukan renungan adalah apakah nilai-nilai budaya Jawa "hidup berdampingan", "tepo sliro", "unggah ungguh" mampu menjadi pilar ketahanan bagi keberadaan pengrajin minyak kelapa? Apakah tanggung jawab sosial bukan lagi dipandang dan diterima menjadi sebuah tanggung jawab namun sudah menjadi nilai keluhuran bagi pelaku industri minyak kelapa sebagai pencipta dampak lingkungan maupun masyarakat sebagai lingkungan terdampak perusahaan? Bagaimana akuntansi sosial diimplementasikan oleh pengrajin minyak kelapa?

Disini dapat dilihat, bahwa masih perlu dicari pemaknaan dari dari tiga frasa yaitu akuntansi sosial, lingkungan terdampak, tanggung jawab sosial yang saling terkait dan melekat, bukan hanya sekedar saling beririsan. Akuntansi sosial mendapatkan perhatian para akuntan, karena perusahaan memiliki kewajiban melakukan perlindungan terhadap lingkungan. Akuntansi sosial ditujukan untuk memberikan informasi kepada stakeholder mengenai kegiatan sosial sebagai bagian program social responsibility. Penelitian akuntansi sosial dan lingkungan mewujudkan berbagai tingkat kesadaran akan masalah global yang kritis dan kebutuhan untuk mengembangkan pendekatan alternatif untuk menangani ekonomi dan masyarakat (Boyce, Prayukvong, Puntasen, 2015). Gray \& Laughlin (2012) melakukan penelaahan terhadap kajian literatur tentang akuntansi sosial dan lingkungan yang dipublikasikan Jurnal Akuntansi, Auditing \& Akuntabilitas dalam kurun waktu 20 tahun. Epstein (2015) juga memberikan tinjauan terhadap literatur akademis dan praktek perusahaan terkait integrasi dampak sosial dan lingkungan ke dalam keputusan pengelolaan yang dipublikasikan selama empat puluh tahun terakhir. Epstein menyarankan tentang kebutuhan penelitian untuk meningkatkan integrasi dampak sosial dan lingkungan ke dalam keputusan manajemen dan meningkatkan pelaporan internal dan pengungkapan eksternal dan akuntabilitas perusahaan. Kedua penelaahan menunjukkan bahwa tinjauan akuntansi sosial dalam konteks perusahaan besar telah dilakukan oleh banyak peneliti sebelumnya.

Dalam konteks penerapan akuntansi sosial oleh industri kecil dan menengah masih memerlukan kajian lebih mendalam. Nilai budaya masyarakat pada lingkungan industri lokal memungkinkan adanya perubahan arah konsentrasi tanggung jawab sosial pemilik. Penelitian ini bertujuan untuk mengetahui penerapan akuntansi sosial yang dilakukan pengrajin minyak 
kelapa dan mencoba mengeksplorasi peran nilai budaya masyarakat dalam pengambilan keputusan tanggung jawab sosial perusahaan.

\section{Metode}

Metode penelitian yang digunakan adalah metode kualitatif dan dianalisis secara deskriptif. Penelitian dilakukan di Desa Kedungkamal, Kecamatan Grabag Kabupaten Purworejo. Informasi diperoleh berdasarkan partisipasi langsung peneliti dan hasil wawancara dengan pihak terkait yaitu pengrajin minyak kelapa, pekerja, beberapa warga sekitar dan tokoh masyarakat setempat. Partisipasi langsung dilakukan dengan tinggal di wilayah obsevasi. Wawancara dilakukan mulai akhir bulan November hingga awal bulan Desember 2020.

\section{Hasil Dan Pembahasan}

Industri minyak kelapa ditinjau dari manfaat ekonomi bagi masyarakat sekitar. Industri minyak kelapa menjadi sumber pendapatan bagi sebagian masyarakat di Desa Kedungkamal, Kecamatan Grabag, Kabupaten Purworejo. Serangkaian kegiatan dari proses produksi minyak kelapa dapat dinikmati antara lain oleh pemilik pohon kelapa, masyarakat pencari kerja dan terutama bagi pengrajin minyak kelapa.

Penulis melakukan wawancara dengan salah seorang warga mengenai kepemilikan pohon kelapa dan beliau menjelaskan

"Hampir setiap keluarga di sini memiliki pohon kelapa meskipun hanya beberapa saja. Kami tidak menanam karena pohon kelapa yang bisa kita temui di sepanjang jalan sudah tumbuh dari jaman dahulu kala. Biasanya buah kelapa dimanfaatkan untuk memenuhi kebutuhan memasak sendiri. Secara berkala kelapa akan dibeli oleh pengrajin minyak kelapa, lumayan bisa digunakan untuk membantu keperluan sehari-hari”.

Berdasarkan wawancara tersebut,penulis menyimpulkan bahwa keberadaan industri minyak kelapa telah mempermudah penjualan buah kelapa para pemilik pohon. Penjualan langsung memberi keuntungan lebih karena tidak perlu menjual ke pasar.

Wawancara juga dilakukan dengan seorang ibu rumah tangga yang bekerja paruh waktu di industri minyak kelapa dan beliau menjelaskan

"Saya sudah bertahun-tahun bekerja di Bapak N, tugas saya mencukil kelapa. Upahnya lumayan untuk menambah kebutuhan sehari-hari. Kerjanya sebentar saja tidak seharian sehingga masih bisa mengurus anak-anak. Kalau sedang musin panen, saya memilih jadi buruh di sawah. Tapi suami saya bekerja di sana penuh waktu, Berangkat dari pagi sekali sebelum subuh pulang siang"

Berdasarkan wawancara tersebut,penulis menyimpulkan bahwa keberadaan industri minyak kelapa telah dijadikan sumber pendapatan bagi masyarakat sekitar bahkan para ibu rumah tangga di sela-sela kesibukannya sebagai petani dan mengurus keluarga. Industri minyak kelapa telah berkontribusi meningkatan pendapatan masyarakat sekitar sehingga membantu roda perekonomian desa.

Wawancara yang dilakukan dengan pemilik usaha atau disebut pengrajin minyak kelapa, ketika diberi pertanyaan tentang keuntungan usaha beliau menjawab

"Dari hasil usaha minyak kelapa saya bisa menyekolahkan anak-anak, membangun rumah dan investasi lain. Keuntungan dari produksi minyak bisa dikatakan cukup besar. Dalam sehari saya bisa mengantongi keuntungan bersih paling sedikit Rp 500.000,-. Proses produksi selama ini juga lancar tidak ada masalah. Hanya saat musim panen saja saya menurunkan jumlah produksi karena pekerja banyak yang beralih menjadi buruh tani”

Jawaban dari wawancara tersebut, menunjukkan bahwa hasil dari usaha minyak kelapa tidak kalah dengan jenis usaha di bidang lain. Berdasarkan catatan sederhana yang penulis 
peroleh dari beliau, dana dikeluarkan berkisar $\mathrm{Rp} 4.000 .000$ per hari, menghasilkan penjualan minyak kelapa sebesar Rp 4.500.000,-. Mengenai penghitungan laba, pemilik tidak memperhitungkan perannya sebagai pengelola usaha, sekaligus supervisor/mandor yang meluangkan waktunya untuk memantau proses produksi sampai penjualan minyak kelapa.

Dampak positif dan negatif industri minyak kelapa. Keberadaan industri minyak kelapa mempengaruhi sendi kehidupan sehari-hari bagi masyarakat sekitar. Dampak yang diakibatkan oleh proses produksi minyak kelapa beragam, tergantung pada sisi pandang masingmasing unsur masyarakat. Penulis melakukan wawancara dengan pekerja, pemilik, tetangga sekitar tempat produksi dan seorang tokoh masyarakat guna menggali informasi dampak positif maupun negatif dari proses produksi minyak kelapa.

Wawancara dengan pengrajin minyak kelapa menghasilkan kutipan pembicaraan berikut :

"Saya mempekerjakan para tetangga sekitar 15 orang. Pekerja laki-laki bekerja di bagian marut, idek, indel dan ngepres. Mereka bekerja dari sebelum subuh hingga siang hari. Pekerja perempuan diberi tugas untuk pekerjaan cukil. Mereka bekerja pada pagi hari saja, hanya paruh waktu. Kalau musim panen saja sebagian dari mereka minta libur, tapi saya maklumi saja"

Berdasarkan wawancara tersebut dan pengamatan langsung di lapangan, penulis memperoleh iniformasi bahwa proses produksi minyak kelapa meliputi kegiatan cukil (memisahkan daging kelapa dari tempurung), marut (kegiatan marut kelapa), idek (mengambil sari santan kelapa), indel (memasak santan kelapa menjadi minyak) dan Ngepres (memisahkan minyak kelapa dari tepo). Seluruh rangkaian proses produksi tersebut menunjukkan bahwa industri minyak kelapa merupakan usaha "padat karya". Bahkan pada industri minyak kelapa yang lebih besar, kebutuhan pekerja lebih banyak lagi. Penulis tidak memperoleh kesempatan untuk melakukan wawancara dengan pemilik karena kesibukannya. Berdasarkan pengamatan langsung yang dilakukan penulis diperoleh informasi bahwa jumlah pekerja mencapai 25 orang. Dengan demikian setiap industri minyak kelapa membutuhkan sekitar 15 sampai 25 tenaga kerja. Industri ini telah dijadikan alternatif bagi pencari kerja di samping mengerjakan lahan pertanian. Penyerapan tenaga kerja ini merupakan sumbangsih yang sangat besar bagi permasalahan lokal, regional bahkan nasional di Negara Indonesia.

Wawancara dengan seorang ibu rumah tangga yang rumahnya berada di sekitar tempat produksi minyak beliau menjelaskan

"Senang saya melihat ibu-ibu mendapat tambahan penghasilan dengan membantu marut kelapa tiap pagi, mereka lebih produktif. Kalau ditanya keluhan ya ada sih, kalau ada angin baunya menyengat sekali, kadang kalau dini hari saat anak-anak sedang tidur terdengar suara mesin parut yang berisik sekali, tapi selama ini saya maklumi saja, sudah biasa. Bagaimanapun mereka kan tetangga yang sudah bertahun-tahun hidup berdampingan, saling mengerti saja".

Wawancara dengan seorang bapak yang memiliki tanaman pisang di sekitar tempat produksi menghasilkan kutipan berikut :

“ Tanaman pisang saya pindahkan ke lahan lain, karena layu semua kalau di dekat tempat penampungan limbah minyak, daun mengering bahkan nampak seperti terbakar. Nggak enaklah saya kalau harus protes, mengalah saja, pindahkan pohon-pohon pisang ke lahan yang agak jauh"

Wawancara dengan tokoh masyarakat terkait dengan pembinaan yang dilakukan, beliau menjawab

"Sebenarnya dari pemerintah daerah sudah turun bantuan berupa pipa untuk mengalirkan limbah ke sungai besar. Tapi sepertinya masih ada kendala di sambungan pipanya, jadi masih tercium bau menyengat. Pernah juga dimediasi antara pemilik dan masyarakat, tapi kembali lagi pada kebutuhan masyarakat itu 
sendiri yang masih bergantung pada industri minyak kelapa. Bagaimana mata pencaharian mereka kalau proses produksi dihentikan. Sudah puluhan tahun usaha mereka beroperasi”.

Berdasarkan wawancara dengan beberapa pihak penulis menyimpulkan bawa kehadiran indutri minyak kelapa membawa dampak lingkungan yang mengganggu masyarakat sekitar. Dampak lingkungan meliputi kerusakan struktur tanah, polusi udara dan mengganggu kenyamanan. Kearifan dan nilai-nilai kekeluargaan, kebersamaan, dan saling mengerti meniadakan keluhan yang dialami.

Akuntansi sosial diterapkan oleh industry minyak kelapa. Proses produksi yang dilakukan oleh industri skala besar atau kecil akan menimbulkan dampak bagi masyarakat dan alam semesta. Perusahaan memiliki kewajiban untuk berkomitmen terhadap lingkungan baik lingkungan alam maupun lingkungan sosial sebagai hal yang utama dan tidak terpisahkan dari kegiatan operasional perusahaan. Bidang akuntansi ikut berperan dalam upaya pelestarian lingkungan, yaitu melalui pengungkapan sukarela dalam laporan keuangannya terkait dengan biaya lingkungan. Sistem akuntansi yang didalamnya mengungkapkan akun-akun terkait dengan biaya lingkungan disebut sebagai green accounting atau environmental accounting (Ningsih \& Rachmawati, 2017). Lingkungan dan tanggung jawab sosial tidak dapat terlepas dari dukungan akuntasi sosial. Akuntansi hijau atau disebut akuntansi lingkungan sering diistilahkan akuntansi social dan lingkungan, memiliki makna dan hakikat sebagai sustainability accounting merupakan bagian dari akuntansi social (Lako, 2016). Menilik dari berbagai literatur yang telah dibahas sebelumnya, akuntansi social lebih dievaluasi pada perusahaan besar. Bagaimana dengan operasi perusahaan kecil?

Pembahasan mengenai implementasi akuntansi sosial oleh perusahaan kecil sangat menarik karena memiliki keunikan sesuai dengan pemahaman dan praktik nilai budaya masyarakat setempat. Dalam kasus industri minyak kelapa di Desa Kedungkamal, apakah dapat dinilai bahwa industri tersebut tidak mengimplementasikan akuntansi sosial. Kita kembali pada makna akuntansi sosial, bahwa perusahaan wajib menjaga keharmonisan dengan lingkungan internal maupun eksternal, dengan lingkungan sosial dan lingkungan alam. Pada praktiknya, keharmonisan dengan lingkungan masyarakat telah terjaga dengan "hampir sempurna", simbiosis mutualisme telah mengaburkan makna lingkungan alam yang terdampak operasional perusahaan. Nilai kebersamaan, hidup berdampingan, tepo sliro, unggah ungguh, menjadi pintu utama dalam menjaga keharmonisan perusahaan dengan lingkungan sosial, namun tidak akan menjadi pintu manapun bagi keharmonisan lingkungan alam. Alam tidak dapat berdamai dengan penyebab kerusakan. Pelan dan pasti, global warming akan semakin meningkat. Asas manfaat kehadiran industri minyak kelapa secara ekonomi dan social masyarakat tidak dapat dipungkiri, dari meningkatnya pendapatan masyarakat hingga tejaganya perekonomian desa, dari berkurangnya jumlah pengangguran, dari nilai tambah komoditas buah kelapa.

Peran industri minyak kelapa di Desa kedungkamal menunjukkan bahwa akuntansi social telah dijalankan, namun masih perlu dievaluasi kembali terutama dalam menjaga keseimbangan alam. Tanggung jawab berbagai pihak masih perlu dikaji sehingga dapat melibatkan para aktor. Sesuai dengan konsep penta helix yang awalnya diperkenalkan oleh Carayannis, peranan aktoraktor dalam Quintuple Helix perlu dimaksimalkan. Pemerintah, akademisi, perusahaaan besar, dan komunitas bahu membahu untuk mendapatkan jalan keluar untuk mengatasi permasalahan perusahaan kecil dalam mengelola lingkungan alam. The Quintuple Helix dapat diusulkan sebagai kerangka kerja untuk transdisipliner (dan interdisipliner) analisis pembangunan berkelanjutan dan ekologi sosial (Carayanis, Barth, \& Campbell, 2012). Penelitian ini menyarankan untuk peneliti selanjutnya mengeksplorasi pengembangan model kolaborasi aktor quintuple helix dalam melakukan pendampingan bagi industi kecil dan menengah khususnya industri minyak kelapa. 


\section{Simpulan}

Pengrajin minyak kelapa di Desa Kedungkamal, Kecamatan Grabag kabupaten Purworejo telah mengimplementasikan sebagian akuntansi sosial. Tanggung jawab sosial pada masyarakat telah dilakukan dengan dukungan nilai-nilai budaya setempat namun belum sepenuhnya mampu menjaga keseimbangan lingkungan alam. Penelitian ini masih perlu disempurnakan dengan melibatkan pihak pemerintah daerah, akademisi, komunitas pengrajin minyak kelapa sebagai informan agar informasi yang diperoleh lebih komprehensif. Manfaat dan dampak operasional usaha minyak kelapa masih perlu dikaji lebih mendalam agar mendapatkan solusi yang lebih tepat bagi permasalahan yang ada.

\section{Daftar Pustaka}

Boyce, G., Prayukvong, W., Puntasen, A. (2015). Social Accounting for Sufficiency: Buddhist Principles and Practices, and Their Application in Thailand. In Extending Schumacher's Concept of Total Accounting and Accountability into the 21st Century, 55-119. doi.org/10.1108/S1041-7060(2009)0000014007

Carayannis, E.,G., Barth, T., D., \& Campbell, D., F., J., (2012). The Quintuple Helix Innovation Model Global Warming as Challenge and Driverter Innovation. Jurnal of Innovation and Entrepreneurship.

Epstein, M.J. (2015). The Identification, Measurement, and Reporting of Corporate Social Impacts: Past, Present, and Future. Advances in Environmental Accounting \& Management, Volume 2, 1-29. pp.1-29.

http://dx.doi.org/10.1016/S1479-3598(03)02001-6

Gray, R. \& Richard Laughlin, R. (2012). It was 20 years ago today Sgt Pepper, Accounting, Auditing \& Accountability Journal, green accounting and the Blue Meanies, Accounting, Auditing \& Accountability Journal Vol. 25 No. 2, pp. 228-255. DOI $10.1108 / 09513571211198755$.

Lako, Andreas. (2016). Transformasi Menuju Akuntansi Hijau : Konsep dan Praktik : Disajikan dalam Simposium Nasional Akuntasnsi XIX. Universitas Soegijapranoto Semarang.

Ningsih, W. F., \& Rachmawati, R. (2017). Implementasi Green Accounting dalam Meningkatkan Kinerja Perusahaan. JABE (Journal of Applied Business and Economic), 4(2), 149. https://doi.org/10.30998/jabe.v4i2.2142 